\title{
Quay Cranes in Container Terminals
}

\author{
A. Bartošek*, O. Marek \\ Department of Logistic and Transportation Processes, Czech Technical University in Prague, Czech Republic \\ * Corresponding author: xbartosek@fd.cvut.cz
}

DOI: $10.2478 / \mathrm{v} 10158-012-0027-y$

\begin{abstract}
Container's transport over the world plays a major logistics role in the contemporary global economy. Seaports and their container terminals represent an important function in the logistics chain. The transshipment speed of containers in the container terminal is the significant factor participating in the overall transport time. Quay cranes served as one of the essential elements of the trans-hipment containers in the container terminal. This paper deals with quay cranes, comparing particular specific crane's components. Furthermore, the paper carries out an analysis of the optimal quay crane productivity, with regard to contemporary requirements. At the end of the article requirements for the future development of the quay cranes are submitted.
\end{abstract}

KEY WORDS: Container, quay crane, trolley, hoist, spreader.

\section{INTRODUCTION}

Loading and unloading operations with containers from/to container vessels are performed in the quayside area by quay cranes (QCs). These cranes are found at container terminals, a place where containers are handled from one of the transports (container vessel, feeder vessel etc.) to the other (chassis, automated guided vehicle), and vice versa. QCs are also known as ship-to-shore cranes and they are moved by rail tracks. The first QC (called Portainer) dates back to 1959 and was built by Paceco Corporation. It was first used in a marine terminal in Alameda. Since then, the size of QCs have more than doubled. The first QC was designed to lift $23 \mathrm{t}$ boxes $16 \mathrm{~m}$ over the rails with an outreach of $24 \mathrm{~m}$. The newest gigantic QCs are taller and heavier than any before, which means a height of up to $75 \mathrm{~m}$ and a weight of up to $1,800 \mathrm{t}$ (Super Post-Panamax). It also means that these quay cranes, such as the ones shown in Figure 1 (Super Post-Panamax with Dual hoist tandem $40^{\prime}$, single trolley); lift $65 \mathrm{t}$ boxes $42 \mathrm{~m}$ above the rails with an outreach of $65 \mathrm{~m}$. Current typical size characteristics QCs are shown in Table 1. 


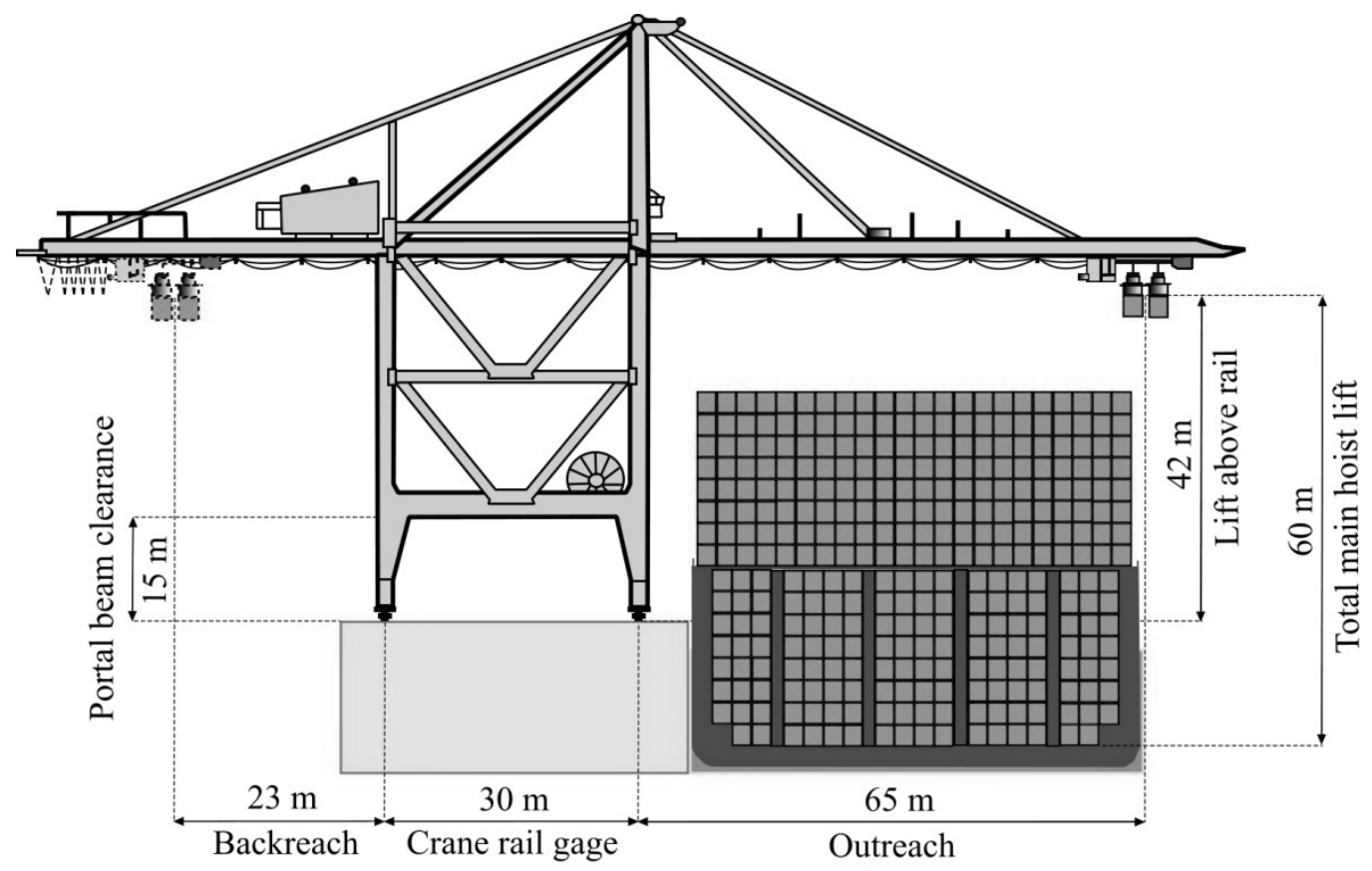

Figure 1: Typical dimensions for the current quay crane.

Table 1: Quay cranes particulars* (Liebher, 2011).

\begin{tabular}{|c|c|c|c|c|c|c|c|c|c|}
\hline : & 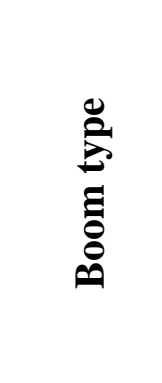 & 芯 & 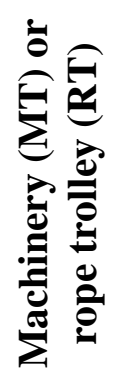 & 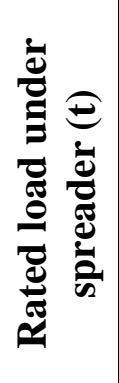 & 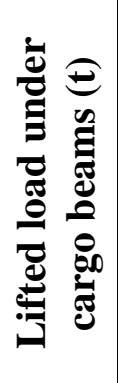 & 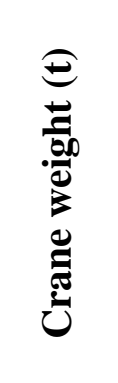 & 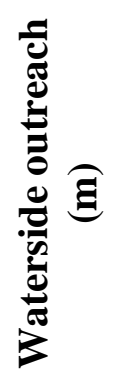 & 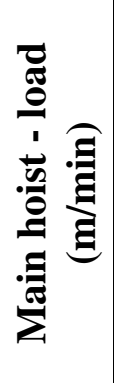 & 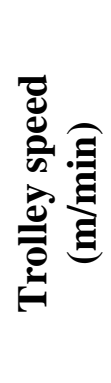 \\
\hline Hamburg & A-frame & Single box & MT & 61 & 84 & 1,410 & 64 & 90 & 210 \\
\hline $\begin{array}{l}\text { Los } \\
\text { Angeles }\end{array}$ & $\begin{array}{l}\text { Low } \\
\text { profile }\end{array}$ & Single box & RT & 61 & 100 & 1,723 & 62 & 75 & 240 \\
\hline Savannah & A-frame & Twin box & RT & 65 & 100 & 1,369 & 61 & 90 & 180 \\
\hline Dubai & A-frame & Twin box & RT & 80 & 100 & 1,280 & 68 & 90 & 240 \\
\hline
\end{tabular}

* The values in this table are approximate.

\section{QUAY CRANES CLASSIFICATION}

QCs are divided into the several categories. The first possible category is a classification according to the size of container vessel, which is able to serve QC:

- Panamax QC - able to transship vessels with 11-13 containers wide (rows) or more and with an outreach 30-40 m. These container vessels are capable of passing through the Panama Canal;

- Post-Panamax QC - able to transship vessels with 17-19 containers wide or more and with an outreach $45-55 \mathrm{~m}$;

- Super Post-Panamax QC - able to transship vessels with 21-23 containers wide and with an outreach $60-70 \mathrm{~m}$. 
These QCs are further classified by the boom mechanization (see Figure 2):

- High profile (so called A-Frame) with tip-up boom above the water surface and prove of vessel anchor (port of Rotterdam). This profile exhibits the lowest cost and the lowest wheel loads;

- Low profile where the boom is able either to push forwards or to push in above vessel deck (port of Boston). These QCs are suitable especially for their minimum height near airports and for reduced visual impact. This profile exhibits higher costs and higher wheel loads.

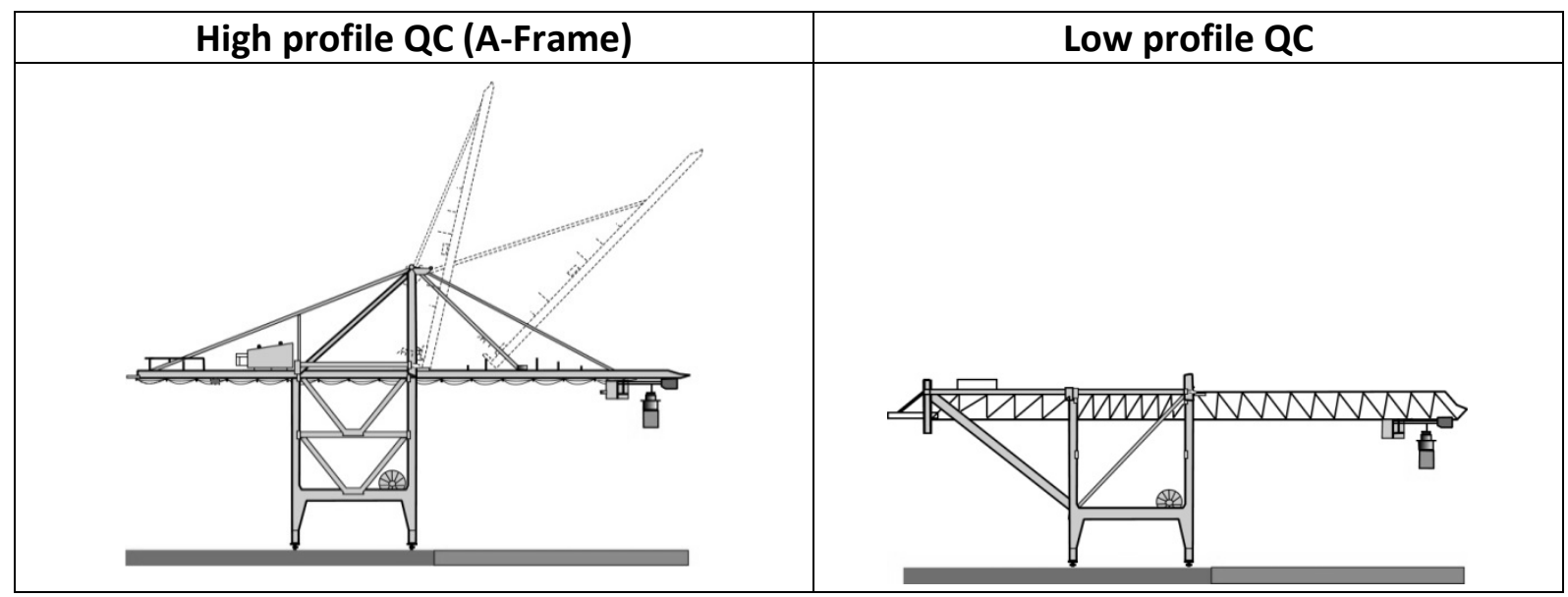

Figure 2: High profile and low profile quay crane.

QCs can be powered by two types of power supplies:

- Alternating current (AC) - AC hoist motors have dedicated inverters where each motor is controlled separately. QC equipped with an AC must be continuously hooked up to an $\mathrm{AC}$ power supply or generator;

- Direct current (DC) - DC hoist motors are wired in a series where only one DC serves to control the motors. QCs equipped with DC can be moved to any location and can operate off a battery supply.

There are, of course, QCs equipped with both power supplies. For example, in the Buchardkai container terminal (Hamburg) where the hoist and trolley have DC and gantry has AC (Marek \& Bartošek, 2011).

\section{CRANE COMPONENTS}

The loading and unloading operation of a container is described as a move. The QC spreader is placed on the container, fixed by twistlocks, than lifted by a hoist, to unload it. The crane's trolley moves the container to the quay where the spreader is lowered and the container is either put on the ground (wharf) or transport vehicle. The container is released by unlocking the twistlocks and the spreader is hoisted again. The loading of a container uses the same crane operations and vice versa (Meisel, 2009). Vessels can be equipped with cell guides for easier positioning of containers within the hold.

Since the end of the $80 \mathrm{~s}$, hoist and trolley speeds have nearly doubled. Of course, everything is affected by the development of motor dimensioning and drive systems. QCs currently have normal hoisting speeds of $180 \mathrm{~m} / \mathrm{min}$ (empty spreader) and $90 \mathrm{~m} / \mathrm{min}$ (rated 
load). Main trolley speed typically varies between $50 \mathrm{~m} / \mathrm{min}$ (Panamax) and $240 \mathrm{~m} / \mathrm{min}$ (Super Post-Panamax). Gantry speed is $70 \mathrm{~m} / \mathrm{min}$ with an acceleration ramp time of four to eight seconds (Kocks, 2011).

The QC trolley selection has to be based on the needs of a particular location, as well as the crane structure and the wheel loads. The QC trolley can be rope towed or machinery type. From the point of the structural design, weight is the main difference between these two types of trolleys, as shown in Table 2. The rope towed trolley system has the trolley drive and main hoist.

Table 2: Trolley comparison matrix (ZPMC, 2011).

\begin{tabular}{|c|c|c|c|c|c|c|c|c|c|}
\hline 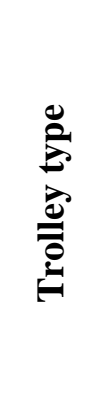 & 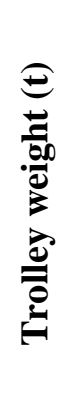 & 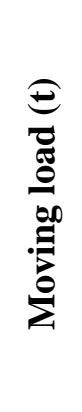 & 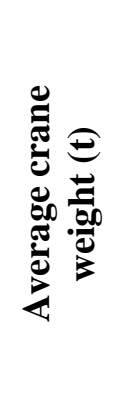 & 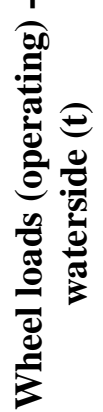 & 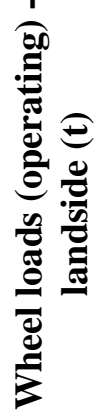 & 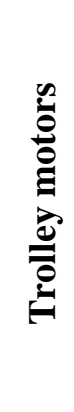 & 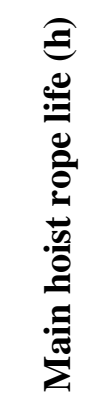 & 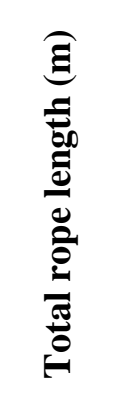 & 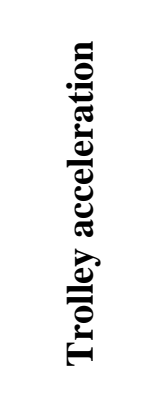 \\
\hline $\mathrm{MT}^{*}$ & 85 & 175 & 1,500 & 220 & 150 & $2-4$ & 3,500 & 500 & High \\
\hline $\mathrm{RT}^{*}$ & 30 & 110 & 1,350 & 200 & 120 & $1-4$ & 1,500 & 3,600 & Average \\
\hline
\end{tabular}

* MT = Machinery trolley, $R T=$ Rope trolley.

Boom hoist drums and machinery are placed in the machinery house, attached to the crane frame. Trolley and main hoist ropes run from the machinery house to the end of the trolley girder, through the trolley, and to the tip of the boom. This layout permits the trolley to be shallow and lightweight, allowing a taller lift and smaller loads on the QC structure and wharf. The rope trolley is common, rope driven is the lightest; if self driven, it is a little heavier. It requires long ropes, catenary trolleys or continuous supports. A machinery trolley has the trolley and main hoist machinery on board. Most of the machinery on the trolley have machinery housings on the frame much smaller, containing only the boom hoist. There are no necessary trolley drive ropes and the main hoist ropes are shorter than for a rope towed trolley (see Figure 3).
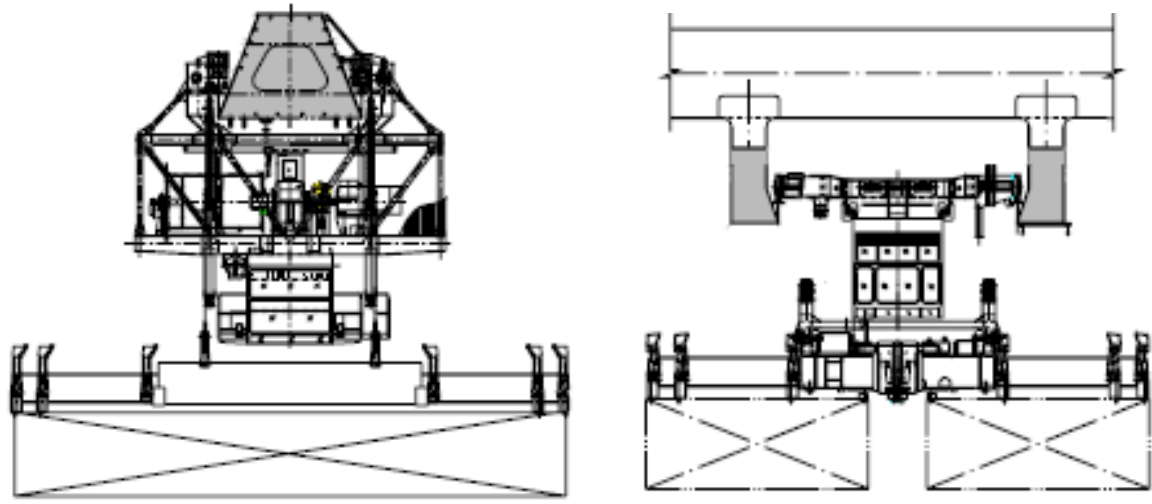

Figure 3: Machinery trolley/monogirder and rope trolley/twin girder (Kalmar, 2011).

Another current typical specification of QC is the so-called portal trolley. A single portal trolley transships the containers between the vessel and the loading/unloading place on the quay. On the other hand, QCs equipped with a double portal trolley are more common 
in recent years. This QC type features a second trolley that runs on the portal beams. The main trolley (waterside) is controlled by the operator. QCs are sometimes operated in a semi-automatic mode, operated by staff only during the actual set-down or pick-up on the vessel.

The rest of the move is fully automatic (landside). It means transship container from lashing (coning) platform to set-down or put on a transport vehicle (horizontal). The lashing platform (buffer position) serves for two $40^{\prime}$ or $20^{\prime}$ containers. QCs equipped with a double trolley can be used for a reduced dwell time. These QCs are used, for example, in Hamburg Altenwerder terminal (Marek \& Bartošek, 2011).

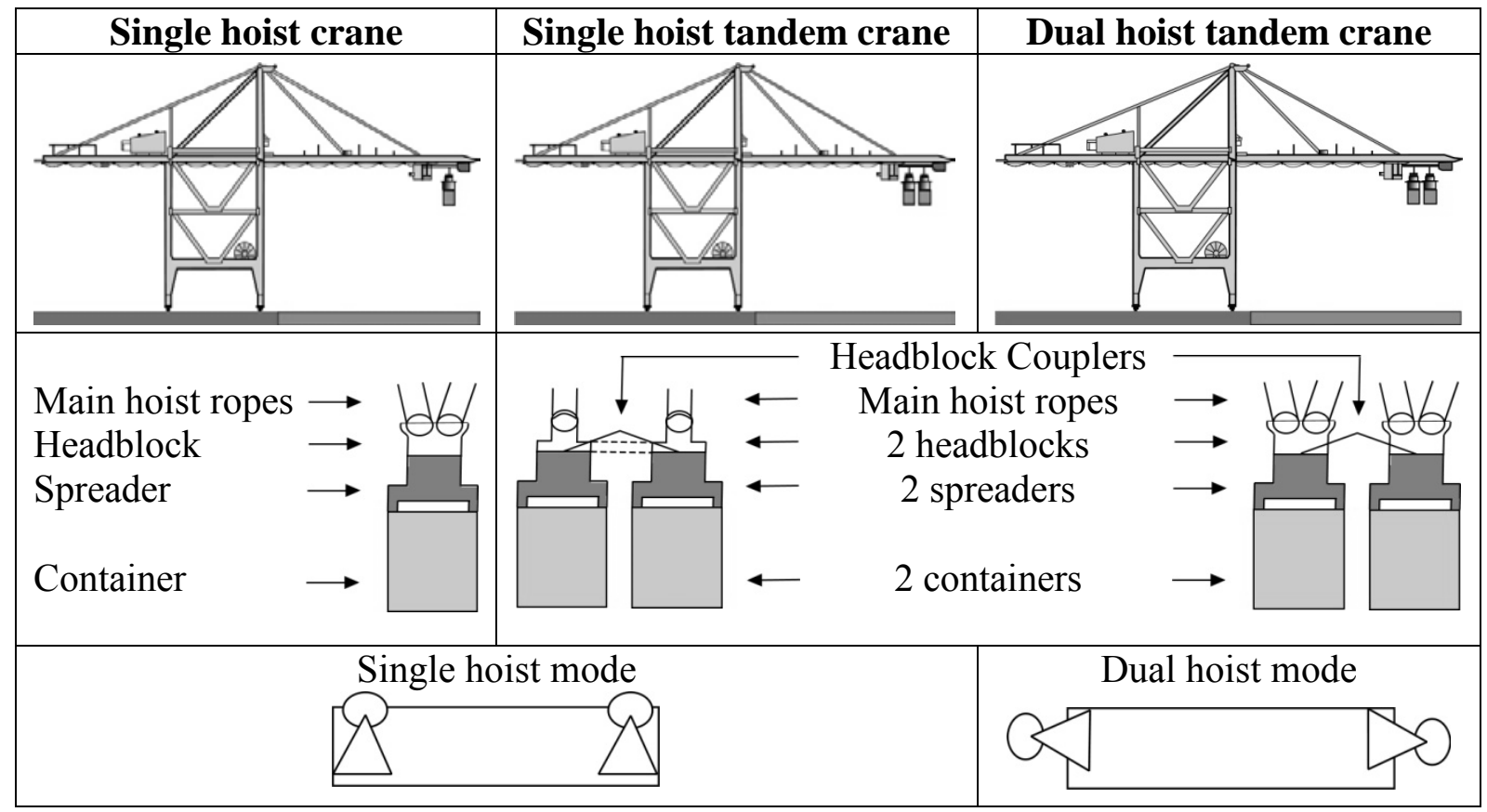

Figure 4: Single hoist and dual hoist (Konecranes, 2012).

QCs can also feature a single or dual hoist, as shown Figure 4. Conventional QCs have a single hoist with a single spreader for a rated load of up to $65 \mathrm{t}$. QC with a single hoist picks up either a single $20^{\prime}, 40^{\prime}, 45^{\prime}$ or two $20^{\prime}$ (twin 20s), under a single spreader. To the contrary dual hoist QC includes two hoisting systems on the main trolley and can handle either two $40^{\prime}$ or four $20^{\prime}$ for each lift (see Figure 5). There are also QCs equipped with a hoist with a tandem. This could double productivity against the conventional single hoist. Tandem means side by side, as opposed to end-to-end twin lifts. These dual hoist tandem QCs are used currently, for example, in the port of Pusan.

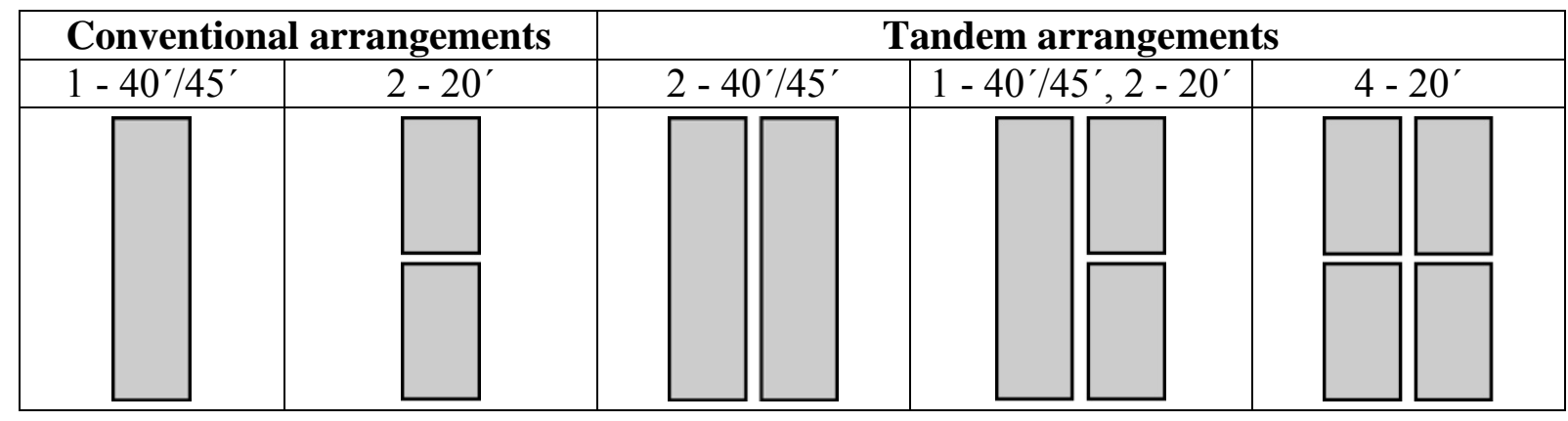

Figure 5: Container arrangements under spreader. 
The most significant differences between the dual hoist QCs and conventional single hoist QCs are:

- Dual hoist QCs are heavier and have bigger wheel loads,

- Dual hoist QCs have larger trolleys, twice as many sheaves, and headblock stowage accommodations,

- Dual hoist QCs have two main hoist systems, two headblocks and conventional spreaders and sets of falls,

- Dual hoist QCs are equipped with ancillary devices to help the operator.

\section{QUAY CRANE PRODUCTIVITY}

Quay crane productivity is a key indicator and one of the critical parts of overall terminal productivity at the same time. The productivity of a QC is measured by the number of moves per hour. One move equals a transship of containers between vessel and transport vehicle in the quay (wharf). QCs are currently able to realize about 30-50 moves per hour in practice, see Table 3 (Post-Panamax, 1.75 TEU per lift). Almost all terminals are able to achieve maximum productivity as low as $70 \%$ and as high as $80 \%$ of the computed number. QCs do not achieve the technically possible productivity due to productivity losses caused by operational disturbances. Nevertheless, technological improvements are increasing QC productivity. The overall time load/unload of vessel is generated from the total sum of loading/unloading containers. This sum is known in practise shortly before the vessel's arrival. The transhipment is determined by the stowage plan. For example, it will take nearly three days to tranship 12,000 TEU vessel and exchange $75 \%$ of its containers, using 6 cranes producing 40 lifts an hour. The effective work means a practical limit up to 6-8 QCs servicing one ship on one quay. While a feeder vessel can be served by 1-2 QCs, big container vessel can be served by up to 8 QCs (Marek \& Bartošek, 2011). The bays of the ship will be partitioned into several areas. Each area will be served by one QC, which is called crane split.

Table 3: Comparison quay crane productivity (Böse, 2011).

\begin{tabular}{|c|c|c|c|c|}
\hline \multirow{3}{*}{ Vessel Size (TEU) } & & pe & & \multirow{3}{*}{ Cranes } \\
\hline & 30 & 40 & 50 & \\
\hline & \multicolumn{3}{|c|}{ Vessel turnaround time (hours) } & \\
\hline 8,000 & 69 & 51 & 41 & 5 \\
\hline 10,000 & 71 & 54 & 43 & 6 \\
\hline 12,000 & 86 & 64 & 51 & 6 \\
\hline
\end{tabular}

The move (travel time) is the simple cycle time from the wharf to the inside ship's hold, shown in Table 4 (single hoist and rope trolley). The hoist and trolley times are parallel and the dwell times are in series. The longer parallel time dominates, the travel time can vary. Depending on the location of the container the hoist or trolley time will dominate.

Table 4: An Example of cycle timeline (Post-Panamax).

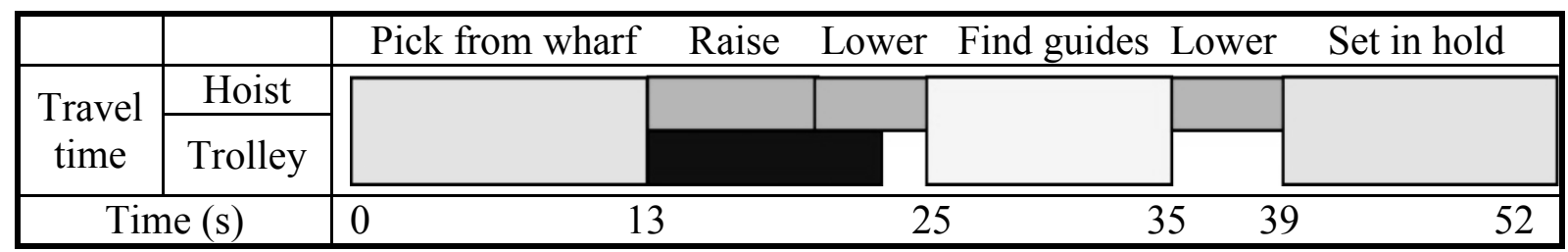


QC equipment variations, such as rope trolley or machinery trolley and single hoist or dual hoist, can make a significant difference in moves per hour, see Figure 6.

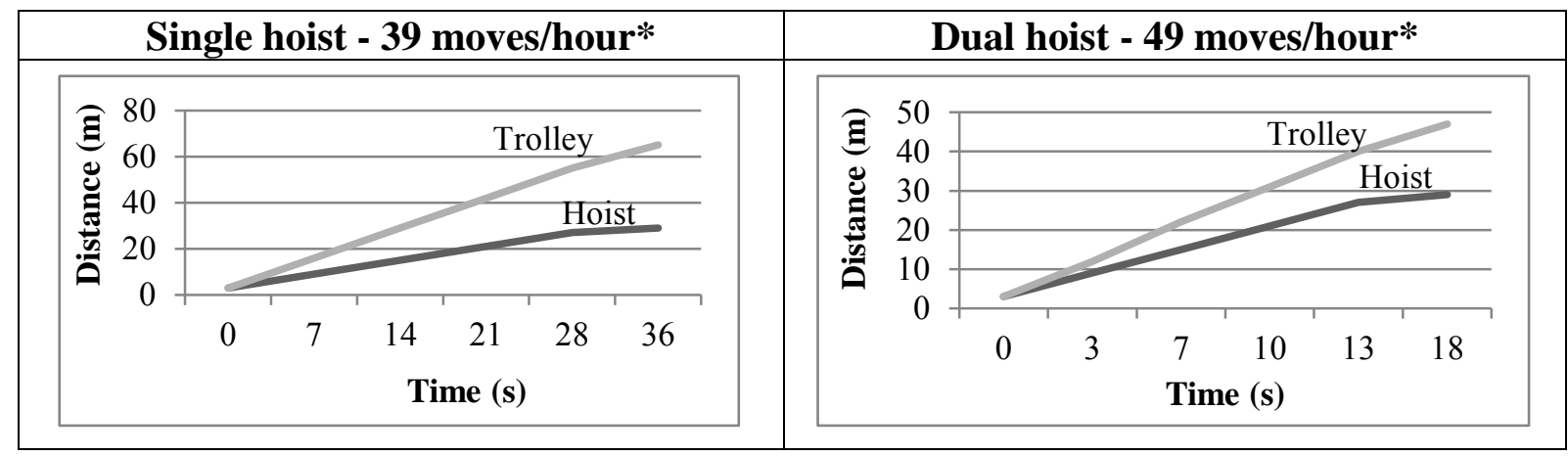

*maximal values

Figure 6: Productivity of single and dual hoist (Rudolf, 2009).

QC productivity (one move) can be computed as a technical output. QC productivity $Q C_{p}$ (TEU) per hour is computed by using this simplified following formula:

$$
Q C_{p}=3,600 \frac{n_{c}}{t_{t}} \cdot t_{p} \cdot c_{t} \cdot f_{t},
$$

where $n_{c}$ is the number of tranship containers in one move [TEU], $t_{t}$ is a theoretical time for one move [s], which is composed of the sum of all time necessary for the transhipment of the container (see chapter 3 and 4). This time is only theoretical, operation productivity (number of moves) can achieve in practise $70 \%$ of theoretical productivity. Therefore, this fact has to be modified by the coefficient of utilization of theoretical productivity $t_{p}$, the value is 0.7. Furthermore, inefficient down time must be included. Waiting time for loading/unloading of containers and other dwell time are expressed by the coefficient of transhipment $c_{t}$. It is also necessary to compute QC failure time, which is expressed by the coefficient $f_{t}$. The aim is to maximize the value of all coefficients up to the value one or totally eliminate them (Dávid, 2009).

\section{REQUIREMENTS FOR THE FUTURE}

QCs should be operational for 25 years, but the effective life will not be more than 20 years. Vessels are currently bigger and bigger and will continue to grow (class Triple-E from Maersk with length $400 \mathrm{~m}$, width $59 \mathrm{~m}$ and capacity up to 18,000 TEU). QCs operated and ordered today have to be capable of serving these new big ships and production has to increase to maintain reasonable turnaround times at the same time. The future-proofs of QCs are shown in Table 5 and illustrate some of the issues that need to be considered.

Table 5: Future-proofs of quay cranes.

\begin{tabular}{|l|l|l|}
\hline \multirow{5}{*}{ Capacity } & Operating load & $\begin{array}{l}\text { Total maximal weight of containers will not increase with } \\
\text { the regard to the valid regulations for the size of containers } \\
\text { and their maximal beam load. Sporadically a much heavier } \\
\text { cargo beam load is admitted. Super Post-Panamax QC } \\
\text { has currently a maximum capacity of between 50-70 t. } \\
\text { For some container terminals 100 t cargo beam capacity } \\
\text { is economical. It is obvious that many more will operate }\end{array}$ \\
\hline
\end{tabular}




\begin{tabular}{|c|c|c|}
\hline & & $\begin{array}{l}\text { tandem spreaders, which are according to numerous papers } \\
\text { economically and capacitively more profitable (for example } \\
\text { Široký, 2011). Hereafter, will more boost triple spreader, } \\
\text { which are able to lift even three } 20^{\prime} \text {. These spreaders } \\
\text { are equipped with Twin-lift technology }\left(2-40^{\prime}\right) \text {, see Figure } \\
\text { 7. It is also possible to take advantage of elevating girder } \\
\text { QCs that enable raising or lowering the height of QC before } \\
\text { vessel service operations begin. Quay crane productivity } \\
\text { can achieved } 50 \text { moves per hour. } \\
\text { Figure 7: Twin-lift spreader for } \mathbf{2}-\mathbf{2 0}, \mathbf{4 0} \text { and tandem twin } \\
\text { lift spreader for a } 2-\mathbf{4 0} \text { (Bromma, 2012). }\end{array}$ \\
\hline \multirow{5}{*}{ Dimension } & Crane rail gage & $\begin{array}{l}\text { The wide crane rail gage is simpler and more stable, } \\
\text { which means no more than } 35 \mathrm{~m} \text {, although there are some } \\
\text { good arguments for increasing the crane rail gage } \\
\text { to as much as } 45 \mathrm{~m} \text {. The cost of transship will be much } \\
\text { greater because the larger crane rail gage cannot be shipped } \\
\text { through vessels. }\end{array}$ \\
\hline & Lift above rail & $\begin{array}{l}\text { The current height should be kept as an optimal, } \\
\text { which means } 42 \mathrm{~m} \text {. It suits present needs for vessels with } 8 \\
\text { containers on deck. When trolley is higher above the wharf } \\
\text { then it is more difficult to control the load. Lift above rails } \\
\text { for future QCs may be increased maximal up to } 50 \mathrm{~m} \text {. }\end{array}$ \\
\hline & Outreach & $\begin{array}{l}\text { Current cranes are able to serve for vessels with } 22-24 \\
\text { containers on deck (i.e. } 60-65 \mathrm{~m} \text { ). The limits for future } \\
\text { growth are represented by the parameters of the Suez Canal } \\
\text { ( } 400 \mathrm{~m} \text { length, } 50 \mathrm{~m} \text { width) and the Malacca Strait ( } 470 \mathrm{~m} \\
\text { length, } 60 \mathrm{~m} \text { width). Furthermore, there are limitations } \\
\text { for the maximal vessel draft, which means that the current } \\
\text { range will in the future be optimal with an economical } 22-24 \\
\text { rows of containers on the deck. Outreach will be increased } \\
\text { later. }\end{array}$ \\
\hline & Backreach & $\begin{array}{l}\text { Contemporary backreach length }(22 \mathrm{~m}) \text { is optimal for future } \\
\text { QCs. Shorter or longer backreach may be reasonable, } \\
\text { but the cost reduction is low. }\end{array}$ \\
\hline & $\begin{array}{l}\text { Portal beam } \\
\text { clearance }\end{array}$ & $\begin{array}{l}\text { Portal beam clearance is } 15 \mathrm{~m} \text { nowadays. This height } \\
\text { is recommended to provide for future transport vehicles, } \\
\text { such as straddle carriers. If the landside operations } \\
\text { will be fully automated then a second hoist may be a rational } \\
\text { addition. } \\
\text { The higher portal beam clearance demands an increased }\end{array}$ \\
\hline
\end{tabular}




\begin{tabular}{|l|l|l|}
\hline \multirow{5}{*}{ Trolley } & Type and speed & $\begin{array}{l}\text { structure to maintain a reasonably solid crane in the trolley } \\
\text { travel direction. }\end{array}$ \\
\hline $\begin{array}{l}\text { Currently the maximum speed of hoist is at } 90 \mathrm{~m} / \mathrm{min} \\
\text { for loading and at } 180 \mathrm{~m} / \mathrm{min} \text { for unloading. The speed will } \\
\text { not increase so much due to the vessel size and capacity. } \\
\text { The trolley type will be either machinery trolley or a rope } \\
\text { trolley, both have pros and cons (see Table 2). } \\
\text { The machinery trolley seems to be better (rope towed } \\
\text { option), but if a rope trolley is used, the ropes should } \\
\text { be coherently supported by the boom and girder, so the load } \\
\text { can be regularly supervised when the landside operation } \\
\text { is fully automated. Among the disadvantages } \\
\text { of the machinery trolley on the wharf belong the increased } \\
\text { QC weight and wheel loads. }\end{array}$ \\
\hline
\end{tabular}

\section{CONCLUSION}

Present-day vessel's size and capacity demands lead to bigger and faster QCs. These QCs have to be capable to serve 22 wide's vessel and to lift $65 \mathrm{t}$ of load under spreader and $100 \mathrm{t}$ under hook rapidly. Fast developing improvements in QC structure, electronical, automatic and optical equipment will reduce dwell times and improve increasing QC productivity. Releasing automation is one of the ways how to increase QC productivity; one of others is to use either a double trolley system or a double hoist system on QCs. These QCs cranes offer high potential capacity, but also require a well-integrated terminal process. From the point of view of the container terminal operator these improvements are perspectived and improving the vessel transshipment time.

\section{ACKNOWLEDGEMENTS}

The research described in this article was established within the framework of the CTU student grant competition in 2011 No. SGS11/139/OHK2/2T/16 "Logistics operations within the framework of container transshipment".

\section{REFERENCES}

Böse, J. W., 2011. Handbook of terminal planning. Berlin: Springer-Verlag. 433 p. ISBN 978-1-4419-8407-4.

Bromma, 2012 [on-line]. (C) Bromma Conquip [cit. 2012-02-05]. Retrieved from: http://www.bromma.com/show.php?id=1182201

Dávid, A., 2009. Kontajnerové prekladače Post Panamax. Doprava a spoje, 1 (1), pp. 1-6. ISSN 1336-7676. (in Slovak)

Kalmar, 2011 [on-line]. (C) 2013 Kalmar Limited [cit. 2011-12-27]. Retrieved from: http://www.kalmarind.co.uk/pages/crane-services.php 
Kocks, 2011 [on-line]. (C) Friedrich Kocks GmbH \& Co KG [cit. 2011-12-30]. Retrieved from: http://www.kocks.de/draht-_und_stabwalzwerke.html?\&L=2

Konecranes, 2012 [on-line]. (C) 2013 Konecranes [cit. 2012-01-18]. Retrieved from: http://www.konecranes.com/portal/eng/equipment/industrial_cranes/industrial_cranes/

Liebher, 2011 [on-line]. (C) Liebher [cit. 2011-12-26]. Retrieved from: http://www.liebherr.com/ MCP/en-GB/products_mcp.wfw/id-11605-0

Marek, O., Bartošek, A., 2011. Logistické operace v rámci překládky kontejnerů v námořních prŕstavech. Perner's Contacts, 6 (4), pp. 249-260. ISSN 1801-674X. (in Czech)

Meisel, F., 2009. Seaside Operations Planning in Container Terminals. Berlin: SpringerVerlag. 168 p. ISBN 978-3-7908-2190-1.

Rudolf, C. D., 2008. Ship-to-Shore productivity: can it keep up with mega-ship size increases? Port technology international, no. 34, pp. 1-5. ISSN 1358-1759.

Široký, J., 2011. Portálové jeřáby s tandemovými spreadery a jejich provozně-ekonomická výhodnost. Perner's Contacts, 6 (1), pp. 349-358. ISSN 1801-674X. (in Czech)

ZPMC, 2011 [on-line]. (C) 2003-2011 Shanghai Zhenhua Heavy Industries Co., Ltd [cit. 201112-27]. Retrieved from: http://www.zpmc.com/showroom/index.html 